Article

\title{
Bioelectricity Generation by Corynebacterium glutamicum with Redox-Hydrogel-Modified Carbon Electrode
}

\author{
Soo Youn Lee ${ }^{1, *}$, Jiho Min ${ }^{2}$, Sangmin Lee ${ }^{1}$, Hana Nur Fitriana ${ }^{1,3}$, Min-Sik Kim ${ }^{1}$, \\ Gwon Woo Park ${ }^{1}$ and Jin-Suk Lee ${ }^{1}$ \\ 1 Gwangju Bio/Energy R\&D Center, Korea Institute of Energy Research, Gwangju 61003, Korea; \\ silverlsm@kier.re.kr (S.L.); Hana3004ap@gmail.com (H.N.F.); kms0540@kier.re.kr (M.-S.K.); \\ werwers@kier.re.kr (G.W.P.); bmjslee@kier.re.kr (J.-S.L.) \\ 2 School of Chemical Engineering, Jeonbuk National University, Jeonju 54896, Korea; jihomin@jbnu.ac.kr \\ 3 Renewable Energy Engineering Department, Korea Institute of Energy Research Campus, University of \\ Science and Technology, Daejeon 34113, Korea \\ * Correspondence: syl@kier.re.kr; Tel.: +82-62-717-2436
}

Received: 8 August 2019; Accepted: 8 October 2019; Published: 11 October 2019

\begin{abstract}
This work studied Gram-positive and weak electricigen Corynebacterium glutamicum for its ability to transfer electrons and to produce bioelectricity in microbial fuel cells (MFCs). The electrochemical and liquid chromatography-mass spectrometry/mass spectrometry (LC-MS/MS) results revealed that $C$. glutamicum had the potential to mediate electron transfer to an electrode by emitting its own extracellular electron shuttles such as flavins. To enhance the current collection from C. glutamicum, a carbon cloth anode was modified with ferrocene-branched chitosan hydrogel (redox-hydrogel). The maximum current density of the ferrocene-branched chitosan redox hydrogel anode with $C$. glutamicum was drastically increased to $120 \mu \mathrm{A} \mathrm{cm} \mathrm{cm}^{-2}$ relative to a bare carbon cloth electrode with C. glutamicum $\left(261 \mathrm{nA} \mathrm{cm}^{-2}\right)$. The power density and polarization curves for the MFC operation with the redox-hydrogel-modified anode showed that C. glutamicum effectively generated bioelectricity by means of the redox-hydrogel anode. The results suggest that, in such an electro-fermentation process, ferrocene-branched chitosan hydrogel grafted onto an anode surface would also facilitate both electron transfer from C. glutamicum to the anode and bioelectricity generation.
\end{abstract}

Keywords: Corynebacterium glutamicum; bioelectricity; redox-hydrogel; carbon cloth electrode

\section{Introduction}

Using a microbial fuel cell (MFC) as a bio-electrochemical system is an alternative power source that directly converts chemical energy in organic matter to electrical energy through the biological ability of electrochemically active bacteria to donate electrons to conductive materials [1-3]. Bacteria that can efficiently couple to electrodes are called electricigens [4]. These electricigens naturally transfer electrons to an electrode in three ways: (i) electron transfer via bacteria-produced redox-active molecules (electron shuttles), (ii) short-range direct electron transfer between cytochromes on the outer membrane and the electrode; and (iii) long-range electron transport through conductive biofilms consisting of an extracellular matrix and motility apparatus (i.e., pili and filament) [1]. Besides, extracellular electron transfer efficiency is dependent on the ability of bacteria to migrate toward and colonize insoluble electron acceptors (electrodes) [5].

Although both Gram-negative and Gram-positive bacteria have the ability to generate electrical energy, favorable electricigens such as Geobacter sp. and Shewanella sp. are Gram-negative [1], while 
Gram-positive bacteria have a thicker, less-conductive membrane, making them much less electroactive. Thus, Gram-positives are capable of mediated electron transfer through exogenous mediators that are either present in the environment or added artificially [4]. Corynebacterium species are one example of Gram-positive electricigens that have been applied in the presence of exogenously-added mediators. Recently, Liu et al. reported that a small electricity output (a maximum power density of $7.3 \mathrm{~mW} \mathrm{~m}^{-2}$ ) by Corynebacterium species (strain MFC03) was observed without any soluble redox mediator. However, when supplemented with the artificial redox mediator anthroquinone-2,6-disulfonate (AQDS), the maximum power density was drastically enhanced from $7.3 \mathrm{~mW} \mathrm{~m}^{-2}$ to $41.8 \mathrm{~mW} \mathrm{~m}^{-2}$ [6]. C. glutamicum, an important Gram-positive industrial bacterium, can utilize oxygen as a preferable terminal electron acceptor in its respiratory system [7-9]. Manipulation of the redox metabolism of C. glutamicum connected with a cathode in a bio-electrochemical reactor system resulted in higher yields of the target product (1-lysine) when supplemented with AQDS [10]. Such results suggest that direct electron transfer between C. glutamicum and an electrode might be difficult. To overcome this difficulty, anode surface modification using biocompatible and functional substrates with exogenous redox mediators has been considered.

To enhance electrical communication between bacteria and an electrode, several polymer materials, such as nafion, polyamine, and polyaniline, have been used to fabricate anodes in MFCs [11,12]. Among them, chitosan, a linear aminopolysaccharide, has attracted interest for its unique chemical functionalities (polycationic and nucleophilic properties) that are suitable for building of a bio-electrode interface. For instance, chitosan can transit from a soluble to insoluble form by a change in $\mathrm{pH}$, can yield a 3-dimensional hydrogel network, and can interact with other functional groups via its amino and hydroxyl groups [13]. Moreover, anodic electron transfer can also be enhanced by suitable redox mediators for bacteria [2].

In the present study, we explored the ability of C. glutamicum to transfer electrons to anode materials by electrochemical and metabolite analyses. In order to promote electrical communication across the bio-electrode interface, the carbon-based anode material was modified by chitosan hydrogel. Additionally, the chitosan hydrogel was chemically branched with an exogenous redox mediator, a ferrocene $(\mathrm{Fc})$ derivate, to enhance the mediated electron transfer from the bacteria to the electrode (Figure 1) [4,14].

A)
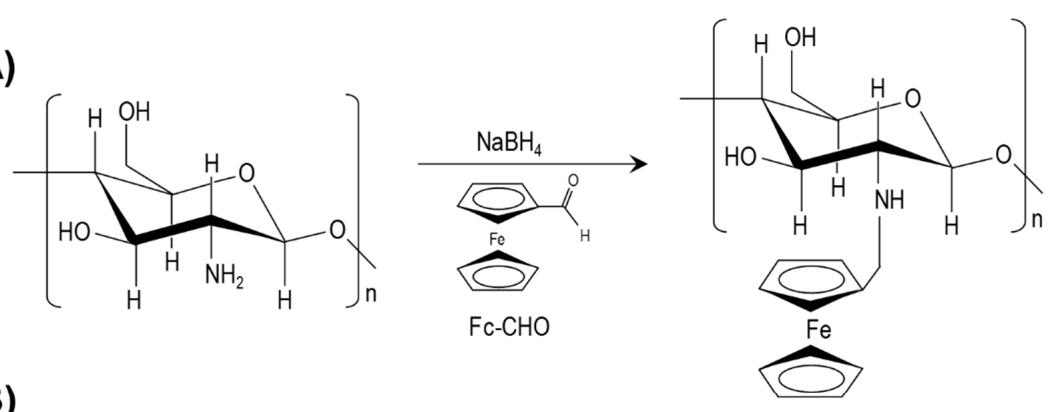

B)
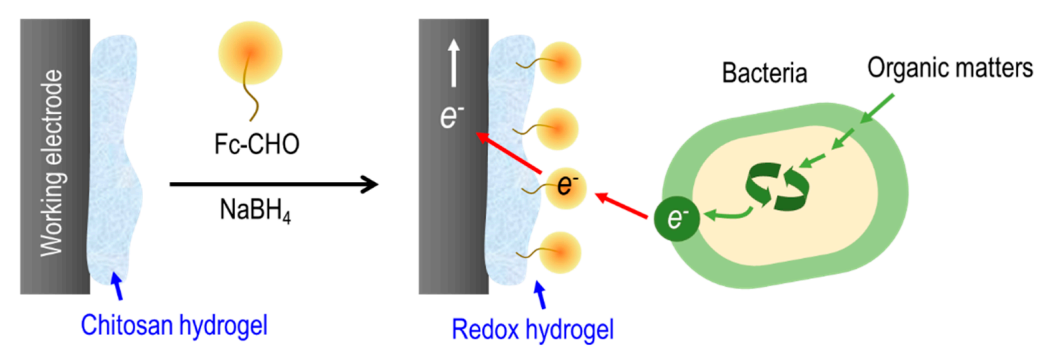

Figure 1. Schematic representation of preparation of redox-hydrogel-modified electrode. (A) Chemical structure of ferrocene-branched chitosan redox hydrogel. (B) Electrochemical interaction of redox-hydrogel-modified carbon cloth electrode with bacteria. 


\section{Materials and Methods}

\subsection{Chemicals}

Carbon cloth and a proton-exchange membrane were purchased from Fuel Cell Store (College Station, TX, USA). Chitosan (Mw 50-190 kDa) and ferrocenecarboxaldehyde $\left(\mathrm{C}_{11} \mathrm{H}_{10} \mathrm{FeO}\right)$ were obtained from Sigma Aldrich (St. Louis, MO, USA). All supplementary chemicals were of analytical grade and used without further purification. All solutions were prepared with $18.2 \mathrm{M} \Omega \mathrm{cm}$ Milli-Q water (Millipore, St. Louis, MO, USA).

\subsection{Bacterial Growth and Cell Preparation}

C. glutamicum ATCC 13032 (America Type Culture Collection, Manassas, VA, USA) was used for MFC operation. Prior to inoculation, C. glutamicum was aerobically cultivated in Luria-Bertani (LB) medium at $30{ }^{\circ} \mathrm{C}$ and $160 \mathrm{rpm}$ for $16 \mathrm{~h}$ and harvested by centrifugation $(8000 \mathrm{rpm}, 10 \mathrm{~min})$ at $4{ }^{\circ} \mathrm{C}$. The cells were washed three times with $50 \mathrm{mM}$ sodium phosphate buffer ( $\mathrm{pH} 7.0$ ), and the cell amount was adjusted to a concentration of $1 \times 10^{9}$ cells $\mathrm{mL}^{-1}$ (determined by viable cell counting). The cell suspension was used as an inoculum for MFC experiments. The anolyte of the MFCs consisted of $0.28 \mathrm{~g} \mathrm{MgSO}_{4} \cdot 7 \mathrm{H}_{2} \mathrm{O}, 10 \mathrm{mg} \mathrm{FeSO} \cdot 7 \mathrm{H}_{2} \mathrm{O}, 8 \mathrm{mg} \mathrm{MnSO}_{4} \cdot \mathrm{H}_{2} \mathrm{O}, 30 \mathrm{mg}$ biotin, $0.5 \mathrm{~g} \mathrm{KH}_{2} \mathrm{PO}_{4}, 0.5 \mathrm{~g} \mathrm{~K}_{2} \mathrm{HPO}_{4}$ and $1 \mathrm{~g}$ Yeast extract (per liter). One percent $(1 \%)$ glucose was used as an electron donor.

\subsection{Fabrication of Redox-Hydrogel-Modified Electrode}

Prior to modification, the bare carbon cloth electrode $\left(1 \times 1 \mathrm{~cm}^{2}, 0.35 \mu \mathrm{m}\right.$-thickness, AvCarb 1071 $\mathrm{HCB}$ ) was immersed in $5 \% \mathrm{HCl}$ solution for $12 \mathrm{~h}$, followed by ultrasonic cleaning in distilled water and then drying in air. Then, chitosan chains comprised of $100 \mathrm{mg}$ of polysaccharide dissolved in $10 \mathrm{~mL}$ of $3 \%(\mathrm{v} / \mathrm{v})$ acetic acid solution were electrodeposited on the electrode by application of a constant current of $6 \mathrm{~A} \mathrm{~m}^{-2}$ for $60 \mathrm{~s}$. For modification, the chitosan-hydrogel-coated electrode was mixed with $10 \mathrm{mg}$ of ferrocenecarboxaldehyde previously dissolved in $10 \mathrm{~mL}$ of distilled water. The mixture was stirred in darkness for $2 \mathrm{~h}$, after which $2 \mathrm{~mL}$ of $0.7 \mathrm{M} \mathrm{NaBH}_{4}$ was added drop-wise under continuous stirring [14]. The reaction mixture was stirred for $4 \mathrm{~h}$. The ferrocene-branched chitosan redox-hydrogel-modified electrode was rinsed with distilled water several times.

\subsection{MFC Construction and Operation}

A two-compartment electrochemical reactor with an anode and cathode was used as a MFC system for bioelectricity generation. The working volume of each compartment was $25 \mathrm{~mL}$. The redox-hydrogel-modified anode and platinum-gauze cathode (80-mesh, ALS Co., Ltd., Tokyo, Japan ) were connected to a potentiostat (660E; CHI Instruments, Inc., Austin, TX, USA) by titanium wire (0.5 mm-diameter; resistance, $<1 \mu \Omega \mathrm{cm}^{-2}$, Sigma-Aldrich). The anode and cathode reactor were separated by a proton-exchange membrane (Nifion117; thickness, $183 \mu \mathrm{m}$ ). $\mathrm{Ag} / \mathrm{AgCl}$ (saturated $\mathrm{NaCl}$; $\mathrm{BASi}^{\circledR}{ }^{\circledR}$ Analytical Instruments, West Lafayette, IN, USA) was used as a reference electrode. In the MFC system, the anolyte contained a bacterial inoculum and the catholyte was a $0.1 \mathrm{M}$ sodium phosphate buffer ( $\mathrm{pH}$ 7.0) with air bubbling $\left(2.5 \mathrm{~mL} \mathrm{~min}^{-1}\right)$. During MFC operation, anaerobic conditions were maintained in the anode compartment by supply of $100 \% \mathrm{~N}_{2}$ gas $(0.22 \mu \mathrm{m}$; sterilized, filtered) for $30 \mathrm{~min}$ prior to operation at flow rates of $2.5 \mathrm{~mL} \mathrm{~min}^{-1}$ with magnetic stirrer $(100 \mathrm{rpm})$. Finally, the anode chamber was sealed with butyl rubber stoppers and caps to prevent influx of oxygen. The cathode compartment was oxygenated by constant air bubbling and stirring at $100 \mathrm{rpm}$ with magnetic stirrer. To determine the MFC power production the reactor was held at open circuit potential for one hour, and then the external resistance was decreased from 1000 to $50 \Omega$ every 20 min with the voltage recorded at each resistance. 


\subsection{Analytical Methods}

For electrochemical analysis, a $3 \mathrm{~mm}$-diameter glassy carbon working electrode, a platinum wire counter electrode, and an $\mathrm{Ag} / \mathrm{AgCl}$ reference electrode $(\mathrm{NaCl}, 3 \mathrm{M})$ were used in an electrochemical cell with a working volume of $10 \mathrm{~mL}$. Cyclic voltammetry was performed using a potentiostat $(660 \mathrm{E}$; $\mathrm{CHI}$ Instruments, Inc.). The working electrode was polished with aluminum-water slurries $(0.3 \mu \mathrm{m}$ and $1 \mu \mathrm{m}$-diameter), and the electrochemical cell was completely cleaned. Oxygen was removed from the electrolyte by bubbling it with oxygen-free $\mathrm{N}_{2}$ for 10 min before electrochemical measurements were obtained. The scanning rate applied was $10 \mathrm{mV} \mathrm{s}^{-1}$ within the range of -0.55 to $0.7 \mathrm{~V} .0 .1 \mathrm{mM}$ sodium phosphate buffer ( $\mathrm{pH}$ 7.0) was used as the electrolyte.

For liquid chromatography-mass spectrometry/mass spectrometry (LC-MS/MS) analysis, medium samples and standards were unfiltered so as to prevent loss of compounds caused by adsorption. Centrifuged samples were analyzed by a C 8 reverse-phase column (Kinetex) with a $2.6 \mu \mathrm{m}$ particle size. Eluted compounds were analyzed by a channel electron multiplier (CEM) detector system (API 4000 LC-MS/MS System, AB-SCIEX). Metabolites were monitored by high-performance liquid chromatography (HPLC) using an Accucore C18 column ( $2.6 \mu \mathrm{m}$ particle size, $4.6 \times 150 \mathrm{~mm}$; Thermo Fisher, Waltham, MA, USA). A fluorescence detector (AB-SCIEX) with an excitation wavelength of $440 \mathrm{~nm}$ and an emission wavelength of $525 \mathrm{~nm}$ was employed as well.

Surface views of the bare and chitosan-hydrogel-coated carbon cloth electrodes were obtained using the SUPRA 55VP (Carl Zeiss) at an accelerating voltage of $2 \mathrm{kV}$ after sputter-coating of a thin platinum layer. Bacterial attachment on the electrodes were fluorescently stained with the SYTO9 (Molecular Probes, Eugene, OR, USA) following to manufacturer's instruction. After the incubation step, SYTO9 dye were mixed in the anolyte and samples were soaked again in fresh anolyte for $10 \mathrm{~min}$ to remove excess dye. Bacteria were examined with upright fluorescence microscope equipped a $5 \times$ objective lens (Axio Imager.A2, Carl Zeiss, Germany).

\section{Results and Discussion}

After C. glutamicum cells were inoculated into a reactor containing a glassy carbon electrode, cyclic voltammograms were analyzed. As shown in Figure 2A, both the anodic (oxidation) and cathodic (reduction) currents after $72 \mathrm{~h}$ of bacterial growth (red) were highly increased relative to $24 \mathrm{~h}$ (black). The cyclic voltammogram, after removing bacterial cells (cell-free medium) after $72 \mathrm{~h}$ growth, still maintained its original capacitance (dashed red). Different cyclic voltammetry patterns were also measured at abiotic (medium only) and biotic condition (with bacteria) (Figure S1). Chronoamperometry data (Figure S2) and the mean current densities (Figure 2B) after $72 \mathrm{~h}$ growth with or without bacterial cells (cell-free medium) and poised at $+0.4 \mathrm{~V}$ (vs. $\mathrm{Ag} / \mathrm{AgCl}$ ) were measured to ca. $205.5 \pm 14.7 \mathrm{nA} \mathrm{cm}^{-2}(n=3)$. The results reflect the electrical interaction between the bacteria and the electrode through the extracellular components. 

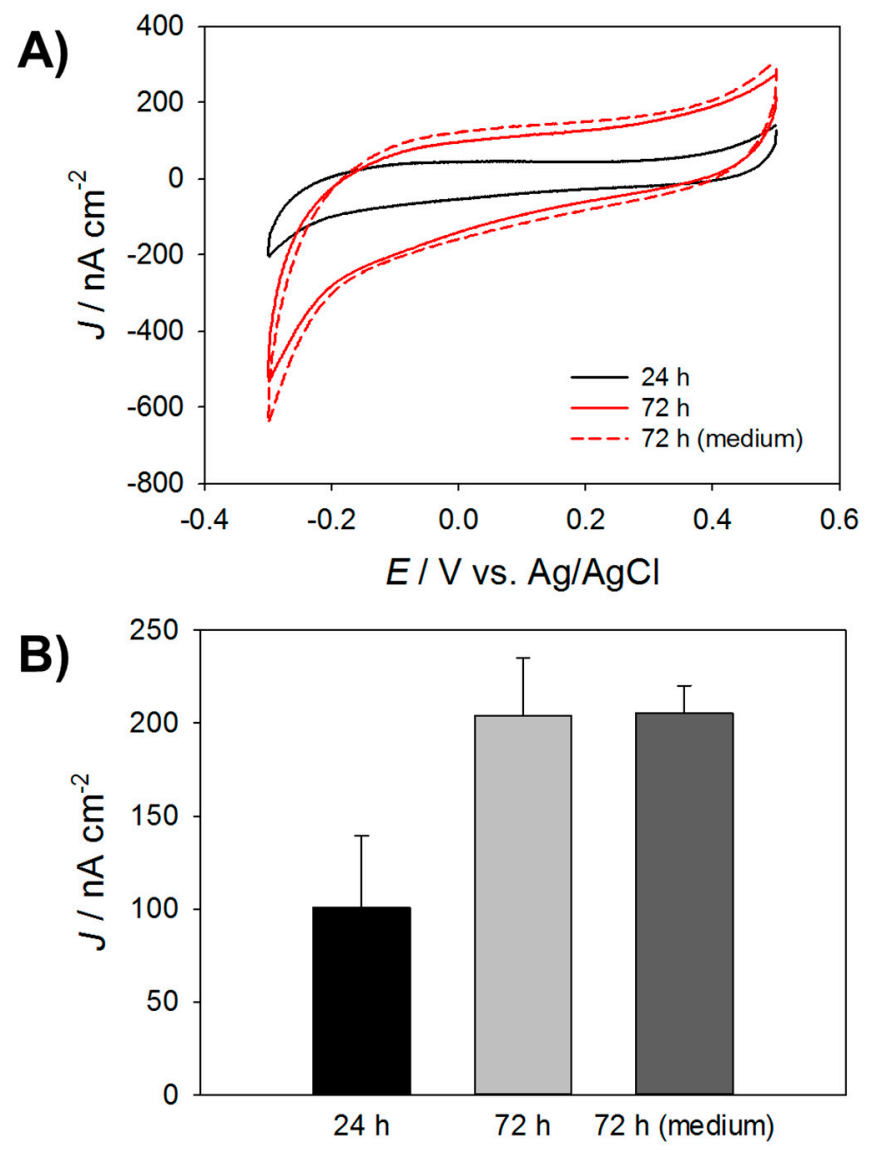

Figure 2. Evidence for secretion of electron shuttle by C. glutamicum. (A) Cyclic voltammograms of glassy carbon working electrode with C. glutamicum growth. (B) Total oxidation current by established C. glutamicum application (poised at $+0.4 \mathrm{~V}$ vs. $\mathrm{Ag} / \mathrm{AgCl}$ ). The y-axis represents the mean value of each current density recording for $600 \mathrm{~s}$. The current densities were measured after $24 \mathrm{~h}$ (with bacteria) and $72 \mathrm{~h}$ (with bacteria or cell-free medium).

According to previous studies, flavins are known to act as an endogenous electron shuttle in electricigen Shewanella species $[15,16]$. Interestingly, C. glutamicum has relative metabolic pathways for endogenous biosynthesis of flavins including riboflavin (vitamin $\mathrm{B}_{2}$ ) and flavin $5^{\prime}$-monophosphate (FMN) [17]. To determine if extracellular electron transfer from C. glutamicum to the anode had occurred, reverse-phase LC-MS coupled with secondary MS analysis was performed with supernatant (cell-free medium) after $72 \mathrm{~h}$ growth of $C$. glutamicum. The results showed that riboflavin had accumulated to $1.67 \pm 0.08 \mu \mathrm{M}$, whereas FMN had accumulated only to $0.07 \pm 0.04 \mu \mathrm{M}$ (data not shown). To explore the electrochemical activity of the extracellular components, the redox peaks of the supernatant (cell-free medium) after $72 \mathrm{~h}$ growth of $C$. glutamicum were scanned by differential pulse voltammetry (DPV). When scanning from negative to positive (Figure $3 \mathrm{~A}$ ) and from positive to negative (Figure 3B), anodic and cathodic peaks centered around $-0.4 \mathrm{~V}$ were detected. The cyclic voltammogram of riboflavin ( $2 \mu \mathrm{M}$ in $0.1 \mathrm{M}$ sodium phosphate, $\mathrm{pH} 7.0$ ), which was a dominant extracellular electron shuttle candidate in this work, also showed anodic $\left(E_{\mathrm{pa}}\right)$ and cathodic $\left(E_{\mathrm{pc}}\right)$ peak potentials around $-0.4 \mathrm{~V}$ (at -0.42 and $-0.45 \mathrm{~V}$, respectively, Figure $3 \mathrm{C}$ ). Besides, a similar shaped voltammogram appeared for flavin-producing microorganisms such as Bacillus sp. WS-WY1 and Pichia stipites [18]. Besides, redox peaks at around $0 \mathrm{~V}$ were presumed that the reduced quinone pool in the respiratory chain in the bacterial cytoplasmic membrane is involved in the extracellular electron transfer [19]. C. glutamicum also possesses a branched electron transport chain via menaquinone in its cytoplasmic membrane [9]. Taken together, these results imply that indirect or mediated electron transfer between $C$. glutamicum and the electrode can occur via extracellular electron shuttles across dense cellular walls [15]. 

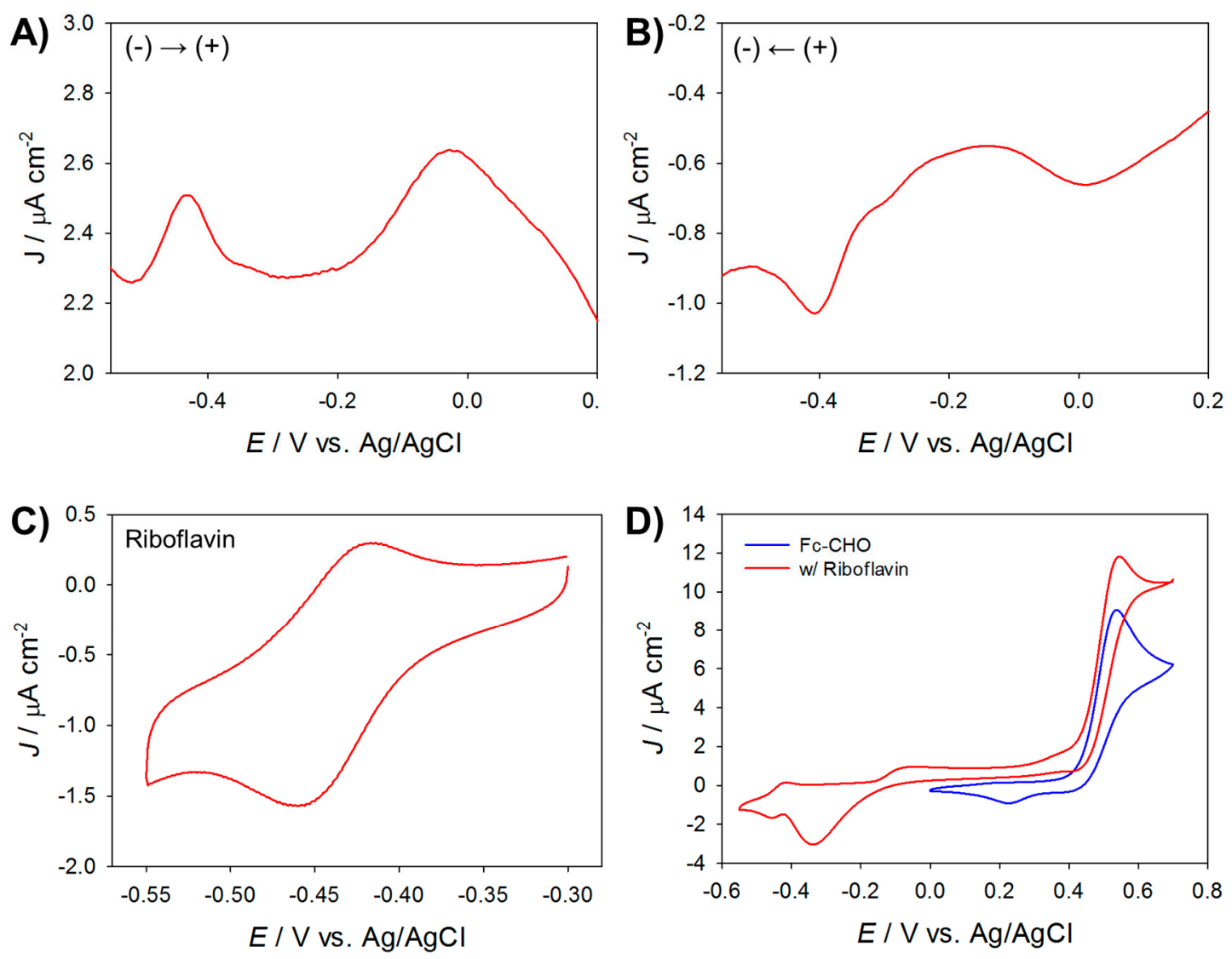

Figure 3. Differential pulse voltammetry (DPV) graphs (A) from negative to positive potentials (oxidation) and (B) from positive to negative potentials (reduction) of glassy carbon electrodes in cell-free medium after $72 \mathrm{~h} \mathrm{C}$. glutamicum growth. (C) Cyclic voltammogram of riboflavin $(2 \mu \mathrm{M})$ and (D) ferrocenecarboxaldehyde ( $\left.\mathrm{Fc}-\mathrm{CHO}, 100 \mu \mathrm{g} \mathrm{mL}{ }^{-1}\right)$ in $0.1 \mathrm{M}$ sodium phosphate buffer $(\mathrm{pH} 7.0)$. Scan rate, $10 \mathrm{mV} \mathrm{s}^{-1}$.

Due to its non-motile character [7], the capacity of an anode for effective current collection from C. glutamicum should be improved (notwithstanding the possibility of its independent production of extracellular electron shuttles). A number of electroactive chemical compounds used as artificial electron mediators have been used to generate bioelectricity such as neutral red, potassium ferricyanide, AQDS, and so on [20]. In particular, ferrocene and its derivatives are renowned due to their biocompatibility, solubility in aqueous phase, and they are easy to conjugate [21]. In this study, cyclic voltammograms of riboflavin and ferrocene derivate were compared to identify an appropriate artificial electron mediator to create an enhanced bioanode with our target bacterium. As shown in Figure 3D, the anodic current of riboflavin, which is a potential endogenous electron shuttle for C. glutamicum, was increased by ferrocene derivate (ferrocenecarboxyaldehyde). Consequently, the anode electrode was fabricated with ferrocene-branched chitosan hydrogel in two steps. First, chitosan hydrogel was deposited electrochemically onto a carbon cloth electrode by immersion in an acidic chitosan solution ( $\mathrm{pH}$ 5.0), and negative voltage was applied to achieve a constant current density $\left(6 \mathrm{~A} \mathrm{~m}^{-2}, 60 \mathrm{~s}\right.$ ) (Figure 4). By applying a constant current, reduction reactions generated localized high $\mathrm{pH}$ adjacent to the electrode, resulting in neutralization of chitosan and triggering its sol-gel transition [13]. 
A)

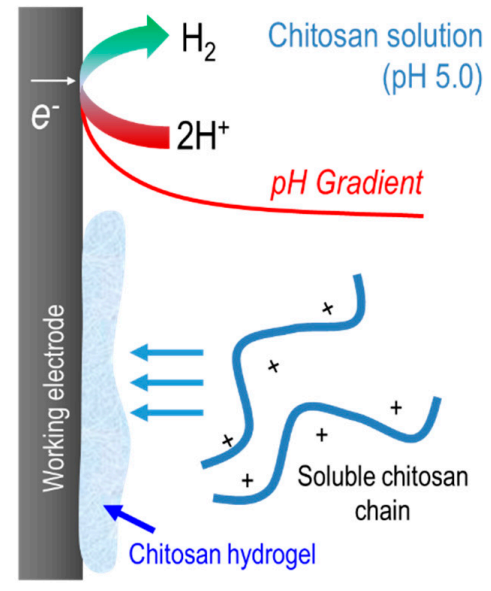

B)

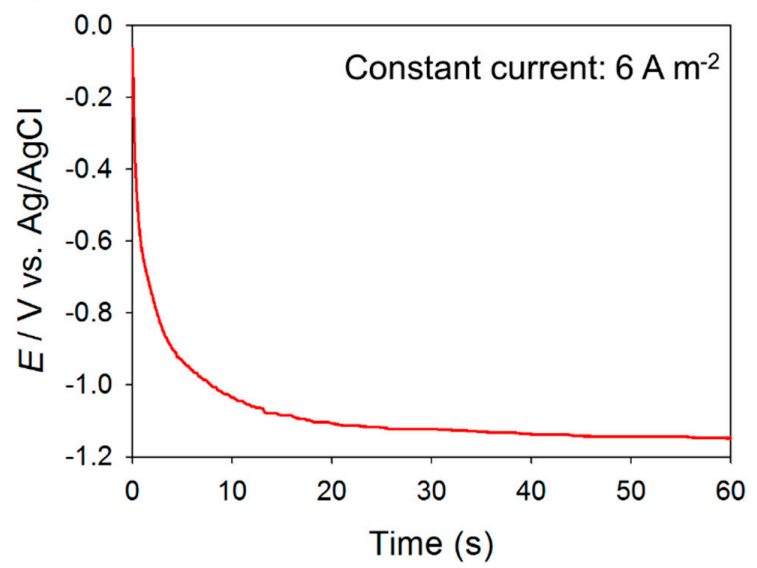

Figure 4. (A) Electrodeposition of chitosan hydrogel. (B) Chronopotentiometry data for chitosan hydrogel formation on carbon cloth anode.

As shown in the obtained scanning electron microscope (SEM) images (Figure 5A,B), the chitosan layer covered the carbon cloth surface. After successful deposition, the chitosan-hydrogel-coated electrode was washed with distilled water. To observe attachment of bacterial cells on the bare and modified electrode, two types of electrodes were immersed into the $C$. glutamicum cultured medium for $72 \mathrm{~h}$. Surface morphologies of C. glutamicum attached electrodes were visualized using a fluorescence microscope after SYTO9 staining (Figure 5C-E). The cells appeared to be more intimately associated with the chitosan-hydrogel coated carbon cloth than the bare electrode. In the second step of anode electrode fabrication, ferrocene was grafted onto the chitosan hydrogel layer by immersion of the chitosan-hydrogel-coated electrode in a solution containing ferrocenecarboxaldehyde (ferrocene- $\mathrm{CHO}$, $1 \mathrm{mg} \mathrm{mL}{ }^{-1}$ ) followed by drop-wise addition of $\mathrm{NaBH}_{4}$ solution with continuous stirring. The layer was stable against exposure to a mild reducing agent $\left(\mathrm{NaBH}_{4}\right)$ for fabrication of the ferrocene-branched chitosan redox-hydrogel (data now shown).

A)

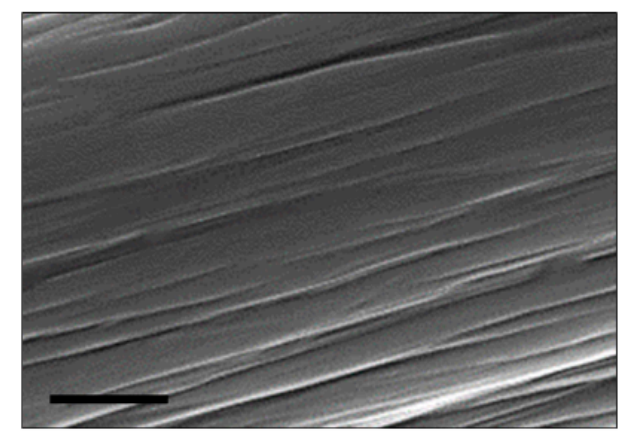

B)

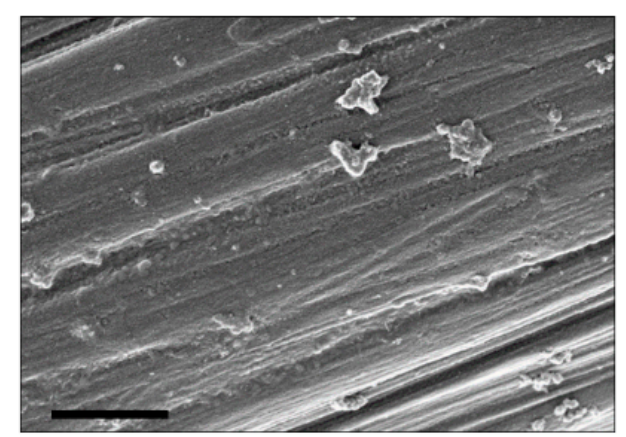

C)

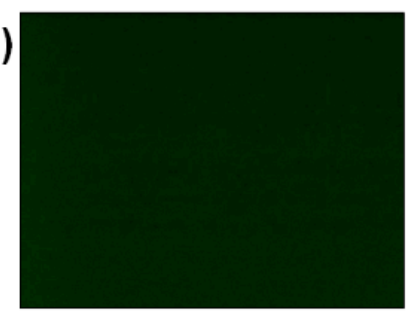

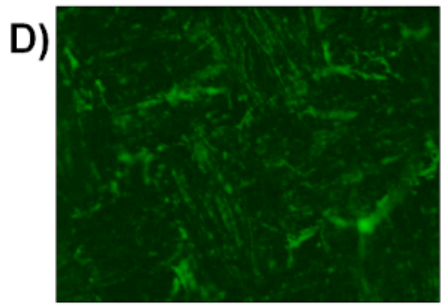

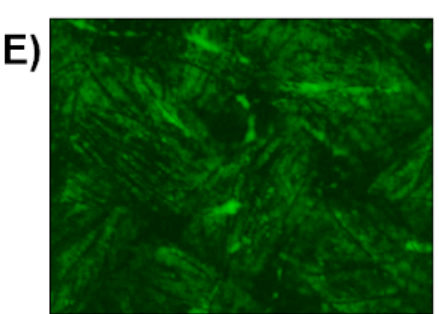

Figure 5. SEM images of (A) bare carbon cloth and (B) chitosan-hydrogel-coated carbon cloth. Scale bar, $1 \mu \mathrm{m}$. Fluorescence microscopic images of (C) chitosan-hydrogel-coated carbon cloth without bacteria, (D) chitosan-hydrogel-coated carbon cloth which were incubated with C. glutamicum for $24 \mathrm{~h}$ and (E) $72 \mathrm{~h}$. Attached bacteria were stained with SYTO9 dye (5× magnification). 
Figure 1B illustrates the hypothesis of direct electron transfer from C. glutamicum to the anode with the aid of the ferrocene-branched chitosan redox-hydrogel. The redox characteristics of the bare carbon cloth (CC), chitosan hydrogel (CC/CS) and ferrocene-branched chitosan redox-hydrogel (CC/CS/Fc) electrodes were compared by cyclic voltammetry $(-0.5$ to $+0.8 \mathrm{~V})$ in $0.1 \mathrm{M}$ sodium phosphate buffer (pH 7.0) (Figure 6A). The similar capacitance of the chitosan hydrogel electrode (CC/CS) to that of the bare electrode (CC) indicated that a thin layer had been grafted onto the electrode by current-controlled electrodeposition [22]. The onset potential and peak potential of the ferrocene-branched chitosan redox-hydrogel electrode $(\mathrm{CC} / \mathrm{CS} / \mathrm{Fc})$ were $-0.13 \mathrm{~V}$ and $+0.36 \mathrm{~V}$, respectively. By contrast, when $C$. glutamicum was applied (CC/CS/Fc with $\mathrm{Cg}$ ), the onset potential was shifted to a more negative potential $(-0.36 \mathrm{~V})$ and a double peak potential originating from indirect electron transfer from the bacteria was observed at $+0.3 \mathrm{~V}$ and $+0.5 \mathrm{~V}$, respectively. The co-presence of ferrocene and C. glutamicum might increase oxidative peak current with double peak potentials originating from bacterial redox systems [23]. As compared with the maximum current density of the bare carbon cloth electrode with $C$. glutamicum ( $261 \mathrm{nA} \mathrm{cm}^{-2}$ at $+0.5 \mathrm{~V}$, Figure $2 \mathrm{~A}$ ), that of the ferrocene-branched chitosan redox-hydrogel anode with $C$. glutamicum (CC/CS/Fc with $\mathrm{Cg}$ ) was drastically increased to $120 \mu \mathrm{A} \mathrm{cm}{ }^{-2}$ at $+0.5 \mathrm{~V}$. Figure $6 \mathrm{~B}$ plots the power density and polarization curves obtained in the $C$. glutamicum MFC with the ferrocene-branched chitosan redox-hydrogel anode $(\mathrm{CC} / \mathrm{CS} / \mathrm{Fc})$ using glucose as an electron donor. The MFC produced a maximum power density of $3.55 \pm 0.27 \mathrm{~W} \mathrm{~m}^{-2}(n=3)$ at a current density of $35.2 \mathrm{~mA} \mathrm{~m}^{-2}$ after $72 \mathrm{~h}$ cultivation, which was higher than that for a Corynebacterium strain MFC03 $\left(41.8 \mathrm{~mW} \mathrm{~m}^{-2}\right)[6]$.

Biofilm formation by bacterial attachment to the electrode surface is essential for bioelectricity generation in MFCs [2]. In this regard, abundant functionalities such as polycationic and nucleophilic properties as well as the stereoscopic scaffold structure of chitosan hydrogel might allow for extensive colonization by electricigens (Figure 5D,E). Indeed, Shewanella oneidensis MR-1, a well-known bacterium for bioelectricity generation, has shown the ability to directly colonize chitosan-carbon nanotube scaffolds $[24,25]$. The ferrocene bound on the modified anode, meanwhile, could serve as a redox mediator for enhanced electron transfer from bacteria to electrode. Recently, the concept of anodic electro-fermentation has been proposed for anaerobic production of l-lysine by the C. glutamicum strain, because it can rely on an anode, instead of oxygen, as a terminal electron acceptor. In the anodic reaction, electrochemical interaction of $C$. glutamicum with the anode was enhanced by providing $\mathrm{K}_{3}\left[\mathrm{Fe}(\mathrm{CN})_{6}\right]$ in electrolyte (cultivation medium) as a redox mediator with the anode at an applied potential of $+0.697 \mathrm{~V}$ (vs. SHE) [26]. This suggests that, in such an electro-fermentation process, ferrocene-branched chitosan hydrogel grafted onto the anode surface would also facilitate both electron transfer from C. glutamicum to the anode and bioelectricity generation. Furthermore, Angelidaki and co-workers reported that metallic modification of electrode, for example, deposition of gold nanoparticles (50 500 nm-thickness) on to the carbon paper electrode, increased the power output of MFCs [27,28]. Based on the results, an extension of our approach, electrode modification with redox-hydrogel, combined with high-capacitant and stereostructural materials would be another effective way to enhance electricity generation in bio-electrochemical systems. 
A)

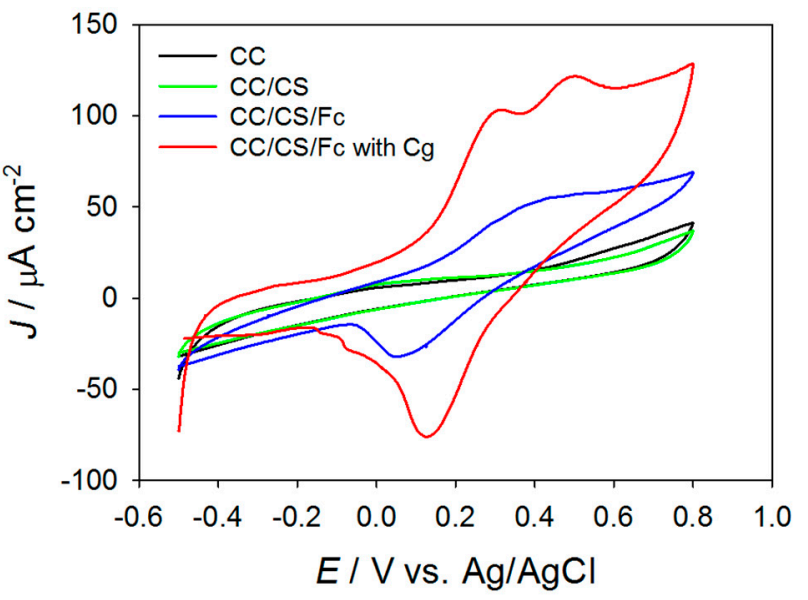

B)

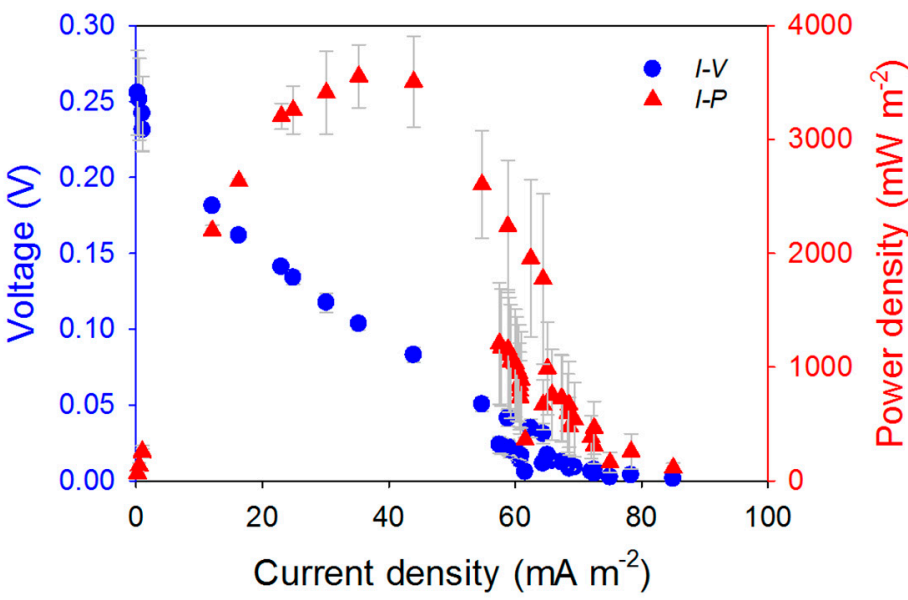

Figure 6. (A) Cyclic voltammograms of redox-hydrogel-modified electrode. CC, bare carbon cloth electrode; CC/CS, chitosan hydrogel modified electrode; CC/CS/Fc, ferrocene-branched chitosan redox-hydrogel modified electrodes, and $\mathrm{Cg}$, C. glutamicum. Scan rate, $10 \mathrm{mV} \mathrm{s}^{-1}$. (B) Voltage and power density measurements as function of applied current for device. Circle symbols (blue), current-voltage (I-V) curve. Triangle symbols, current-power density (I-P) curve.

\section{Conclusions}

In this study, we demonstrated that a Gram-positive and weak electricigen, namely C. glutamicum could produce electricity by emitting potential extracellular electron shuttles. To enhance current collection from C. glutamicum, the carbon cloth anode was modified with chitosan hydrogel by electrodeposition, after which a ferrocene derivative as an exogenous redox mediator was grafted onto the chitosan hydrogel structure. Using glucose as an electron donor, the efficiency of current collection from C. glutamicum was drastically improved by the electrode modification. The results on MFC operation suggested that this weak electricigen generated bioelectricity effectively by means of the redox-hydrogel anode.

Supplementary Materials: The following are available online at http://www.mdpi.com/2076-3417/9/20/4251/s1, Figure S1: Cyclic voltammograms of glassy carbon working electrode with fresh medium (black line), medium only (blue line) and medium with C. glutamicum growth (red line) for $144 \mathrm{~h}$, Figure S2: Chronoamperometry data of C. glutamicum application (poised at $+0.4 \mathrm{~V}$ vs. $\mathrm{Ag} / \mathrm{AgCl}$ ) for $600 \mathrm{~s}$.

Author Contributions: Conceptualization and investigation, S.Y.L.; Bacterial cultivation, S.L. and H.N.F.; Data analysis, J.M. and J.-S.L.; MFC operation, M.-S.K. and G.W.P. All authors have given approval to the final version of the manuscript.

Funding: We acknowledge the financial support from the framework of the Research and Development Program of the Korea Institute of Energy Research (B9-2442-04), the New \& Renewable Energy Core Technology Program 
of the Korea Institute of Energy Technology Evaluation and Planning (KETEP) grants from the Ministry of Trade, Industry and Energy (No. 20173010092460), and Marine Biotechnology Program (20150581, Development of technology for biohydrogen production using the hyperthermophilic archaea) funded by Ministry of Oceans and Fisheries, Korea.

Acknowledgments: The authors thank Taek Dong Chung of Seoul National University, Department of Chemistry, for advising on their electrochemical experiments.

Conflicts of Interest: The authors declare that they have no conflict of interest.

\section{References}

1. Lovley, D.R. Electromicrobiology. Annu. Rev. Microbiol. 2012, 66, 391. [CrossRef] [PubMed]

2. Tang, X.; Ng, H.Y. Anthraquinone-2-sulfonate immobilized to conductive polypyrrole hydrogel as a bioanode to enhance power production in microbial fuel cell. Bioresour. Technol. 2017, 244, 452. [CrossRef] [PubMed]

3. Nealson, K.H. Bioelectricity (electromicrobiology) and sustainability. Microb. Biotechnol. 2017, 10, 1114. [CrossRef] [PubMed]

4. Doyle, L.E.; Marsili, E. Weak electricigens: A new avenue for bioelectrochemical research. Bioresour. Technol. 2018, 258, 354. [CrossRef] [PubMed]

5. Oram, J.; Jeuken, L.J.C. Tactic response of Shewanella oneidensis MR-1 toward insoluble electron acceptors. MBio 2019, 10, e02490. [CrossRef] [PubMed]

6. Liu, M.; Yuan, Y.; Zhang, L.; Zhang, L.; Zhou, S.; Ni, J. Bioelectricity generation by a Gram-positive Corynebacterium sp. strain MFC03 under alkaline condition in microbial fuel cells. Bioresour. Technol. 2010, 101, 1807. [CrossRef] [PubMed]

7. Jost, D.; Winter, J.; Gallert, C. Distribution of aerobic motile and non-motile bacteria within the capillary fringe of silica sand. Water Res. 2010, 44, 1279. [CrossRef]

8. Hermann, T. Industrial production of amino acids by coryneform bacteria. J. Biotechnol. 2003, $104,155$. [CrossRef]

9. Bott, M.; Niebisch, A. The respiratory chain of Corynebacterium Glutamicum. J. Biotechnol. 2003, $104,129$. [CrossRef]

10. Xefenias, N.; Kmezik, C.; Mapelli, V. Enhancement of anaerobic lysine production in Corynebacterium electrofermentations. Bioelectrochemistry 2017, 117, 40. [CrossRef]

11. Wu, W.; Niu, H.; Yang, D.; Wang, S.; Jiang, N.; Wang, J.; Lin, J.; Hu, C. Polyaniline/carbon nanotubes composite modified anode via graft polymerization and self-assembling for microbial fuel cells. Polymers 2018, 10, 759. [CrossRef] [PubMed]

12. Lee, S.Y.; Lim, S.Y.; Seo, D.; Lee, J.Y.; Chung, T.D. Light-driven highly selective conversion of $\mathrm{CO}_{2}$ to formate by electrosynthesized enzyme/cofactor thin film electrode. Adv. Energy Mater. 2016, 6, 1502207. [CrossRef]

13. Kim, E.; Xiong, Y.; Cheng, Y.; Wu, H.C.; Liu, Y.; Marrow, B.H.; Ben-Yoav, H.; Ghodssi, R.; Rubloff, G.W.; Shen, J.; et al. Chitosan to connect biology to electronics: Fabricating the bio-device interface and communicating across this interface. Polymers 2015, 7, 1-46. [CrossRef]

14. Garcia, A.; Peniche-Covas, C.; Chico, B.; Simpson, B.K.; Villalonga, R. Ferrocene branched chitosan for the construction of a reagentless amperometric hydrogen peroxide biosensor. Macrobol. Biosci. 2007, 7, 435. [CrossRef] [PubMed]

15. Marsili, E.; Baron, D.B.; Shikhare, I.D.; Coursolle, D.; Gralnick, J.A.; Bond, D.R. Shewanella secrets flavins that mediate extracellular electron transfer. Ploc. Natl. Acad. Sci. USA 2008, 105, 3968. [CrossRef] [PubMed]

16. Huang, B.; Gao, S.; Xu, Z.; He, H.; Pan, X. The functional mechanisms and application of electron shuttles in extracellular electron transfer. Curr. Microbiol. 2018, 75, 99. [CrossRef] [PubMed]

17. García-Angulo, V.A. Overlapping riboflavin supply pathways in bacteria. Crit. Rev. Microbiol. 2017, 43, 196. [CrossRef] [PubMed]

18. Wu, S.; Xiao, Y.; Wang, L.; Zheng, Y.; Chang, K.; Zheng, Z.; Yang, Z.; Varcoe, J.R.; Zhao, F. Extracellular electron transfer mediated by flavins in gram-positive Bacillus sp. WS-XY1 and yeast Pichia Stipites. Electrochim. Acta 2014, 146, 564. [CrossRef]

19. Pankratova, G.; Leech, D.; Gorton, L.; Hederstedt, L. Extracellular electron transfer by the gram-positive bacterium Enterococcus Faecalis. Biothemistry 2018, 57, 597. [CrossRef] 
20. Liu, X.; Shi, L.; Gu, J. Microbial electrocatalysis: Redox mediators responsible for extracellular electron transfer. Biotechnol. Adv. 2018, 36, 1815. [CrossRef]

21. Şahin, S.; Wongnate, T.; Chuaboon, L.; Chaiyen, P.; Yu, E.H. Enzymatic fuel cells with an oxygen resistant variant of pyranose-2-oxidase as anode biocatalyst. Biosens. Bioelectron. 2018, 107, 17. [CrossRef] [PubMed]

22. Kim, E.; Gordonov, T.; Bentley, W.E.; Payne, G.F. Amplified and in situ detection of redox-active metabolite using a biobased redox capacitor. Anal. Chem. 2013, 85, 2102. [CrossRef] [PubMed]

23. Fricke, K.; Harnisch, F.; Schröder, U. On the use of cyclic voltammetry for the study of anodic electron transfer in microbial fuel cells. Energy. Environ. Sci. 2008, 1, 144. [CrossRef]

24. Rabaey, K.; Boon, K.; Siciliano, S.D.; Verhaege, M.; Verstraete, W. Biofuel cells select for microbial consortia that self-mediate electron transfer. Appl. Environ. Microbiol. 2004, 70, 5373. [CrossRef]

25. Higgins, S.R.; Foerster, D.; Chung, A.; Lau, C.; Bretschger, O.; Minteer, S.D.; Nealson, K.; Atanassov, P.; Cooney, M.J. Fabrication of macroporous chitosan scaffolds doped with carbon nanotubes and their characterization in microbial fuel cell operation. Enzym. Microb. Technol. 2011, 48, 458. [CrossRef]

26. Vassilev, I.; Gießelmann, G.; Schwechheimer, S.K.; Wittmann, C.; Virdis, B.; Krömer, J.O. Anodic electro-fermentation: Anaerobic production of 1-lysine by recombinant Corynebacterium Glutamicum. Biotechnol. Bioeng. 2018, 115, 1499. [CrossRef]

27. Alatraktchi, F.A.; Noori, Z.J.S.; Angelidaki, I. Surface area of electrodes with grass-like nanostructures and gold nanoparticles to enhance electricity generation in microbial fuel cell. Bioresour. Technol. 2012, 123, 177. [CrossRef]

28. Alatraktchi, F.A.; Zhang, Y.; Angelidaki, I. Nanomodification of the electrodes in microbial fuel cell: Impact of nanoparticle density on electricity production and microbial community. Appl. Energy 2014, 116, 216. [CrossRef]

(C) 2019 by the authors. Licensee MDPI, Basel, Switzerland. This article is an open access article distributed under the terms and conditions of the Creative Commons Attribution (CC BY) license (http://creativecommons.org/licenses/by/4.0/). 